\title{
Tradition and the Art of Modern India
}

\author{
Kieran Browne
}

Notions of tradition are complicated when discussed in relation to non-Western modernisms, such as that of India. Traditions resisting change have either been reinvented and modernised without consent, or abandoned in favour of those that are applicable to a modern world. KG Subramanyan is one artist who has moved to assimilate the traditional and the modern in a twentieth century Indian context. His work appropriates elements of Indian visual tradition, as well as popular and classical elements and reinterprets them through modernist forms and techniques. His works Girl with pigeons (1959-1960), Woman with lamp 1 (1951) and Industry (1955) inherit global visual culture, containing elements of Hindu iconography, Euro-American modernism and classical fresco painting. Subramanyan characterises a key section of the broader Indian modernist movement, which seeks to redefine tradition as a living, changing language. This essay argues that the interaction of tradition and modernity in India is indicative of a broader reality: that tradition is a fluid, living form.

Tradition is in flux, finding its ideas and practices constantly reinvented to suit present purposes. In the development of non-Western modernisms, such as that of India, visual traditions have collided with external elements, such as those from Europe. Unlike the Western avant-garde, which has typically met tradition with hostility, Indian modernist artists have moved to assimilate the traditional and the modern, reinventing both in a twentieth century Indian context. ${ }^{1}$ The role of tradition in modern culture is a key concern for Indian modernists and has been explored by influential Indian artists and groups including Rabindranath Tagore, Nandalal Bose and the Bombay Progressives. This essay examines the work of Subramanyan, one of India's most influential artists and educators. ${ }^{2}$ Subramanyan's examination of tradition, both as an artist and art theorist, has influenced many distinguished artists and made a clear imprint on Indian modern and contemporary art. ${ }^{3}$ This consideration of Subramanyan's work explores his background and influences and the expression of tradition in his work through religious iconography and global influences. The essay concludes by examining contradictions in the notion of tradition, and the need for reinvention in order to sustain culture.

\footnotetext{
R Siva Kumar, 'Modern Indian Art: A Brief Overview', Art Journal Vol. 58 No. 3 (1999): 14.

Karin Zitzewitz, 'The Secular Icon', Visual Anthropology Review Vol. 24 No. 1 (2008): 12.

Balrah Khanna \& Aziz Kurtha, Art of Modern India (London: Thames and Hudson, 1998), 38.
} 
'Tradition' is difficult to define in relation to non-Western modernisms. The dichotomy of the traditional and modern, as it is often understood in the West, is not transferable to Indian culture. Tradition can be defined as the craft and language of culture: 'craft' refers to the methods, materials and tools used in any creative endeavour while 'language' refers to the images and ideas that inform the creator. By this definition, modernism is itself a tradition with its own craft and language. For this reason, in order to explore the relationship between the modern and the traditional, it is useful to refer to pre-modern elements of Indian artistic tradition, such as Hindu and Mughal history, as 'indigenous tradition'.

Subramanyan was born in Kerala, south-west India, in 1924. As was typical of the region, he received a good education and had ready access to a Frenchadministered library where he discovered the writings of Indian intellectuals and, amongst many French magazines, The Modern Review. ${ }^{4}$ As a young man he was involved in a number of political movements and led student protests during his time at university in Madras, where he spent six months in jail for his activism. On Subramanyan's release in 1943, Bose, then head of VisvaBharati University, Santiniketan, invited him to study at the university. There, Subramanyan developed an ideological framework for his artistic practice that was profoundly influenced by Bose as well as Tagore, the university's founder. ${ }^{5}$ The doctrine that pervaded teaching at Visva-Bharati was that tradition informs community, which in turn nurtures individuals and culminates in tradition being advanced by an individual's artistic practice. ${ }^{6}$ Subramanyan understood artistic and visual traditions of India and the wider world; he believed artists must abbreviate and reinvent the elements of the visual language they consume. ${ }^{7}$ Influenced by popular, modern, classical and indigenous traditions, Subramanyan's artistic practice was concerned with assimilating these fluid traditions and reinventing them for present purposes.

The fluidity of tradition can be seen in the integration of modernism and indigenous tradition that occurred in India in the twentieth century. For many Indian modernist artists, Hindu iconography was an important part of the Indian artistic tradition, which their work revived and re-imagined during this period. ${ }^{8}$ The use of Hindu iconography for artists at the time was as much a visual form of secularism as an aesthetic decision. ${ }^{9}$ At that time there was widespread use of religious imagery by Hindu nationalists as a symbol of Hindu cultural and

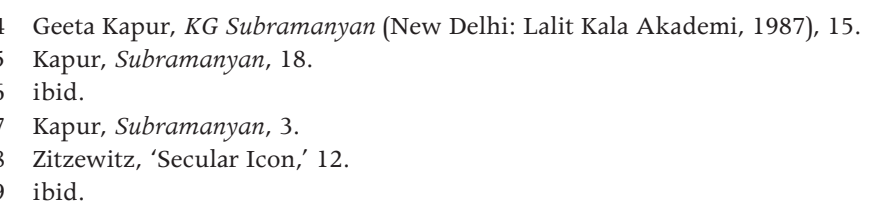


political domination. This political trend, which excluded non-Hindus, was a cause for concern amongst intellectuals and prompted many modernist artists to reclaim the icons through a series of secular appropriations. ${ }^{10}$

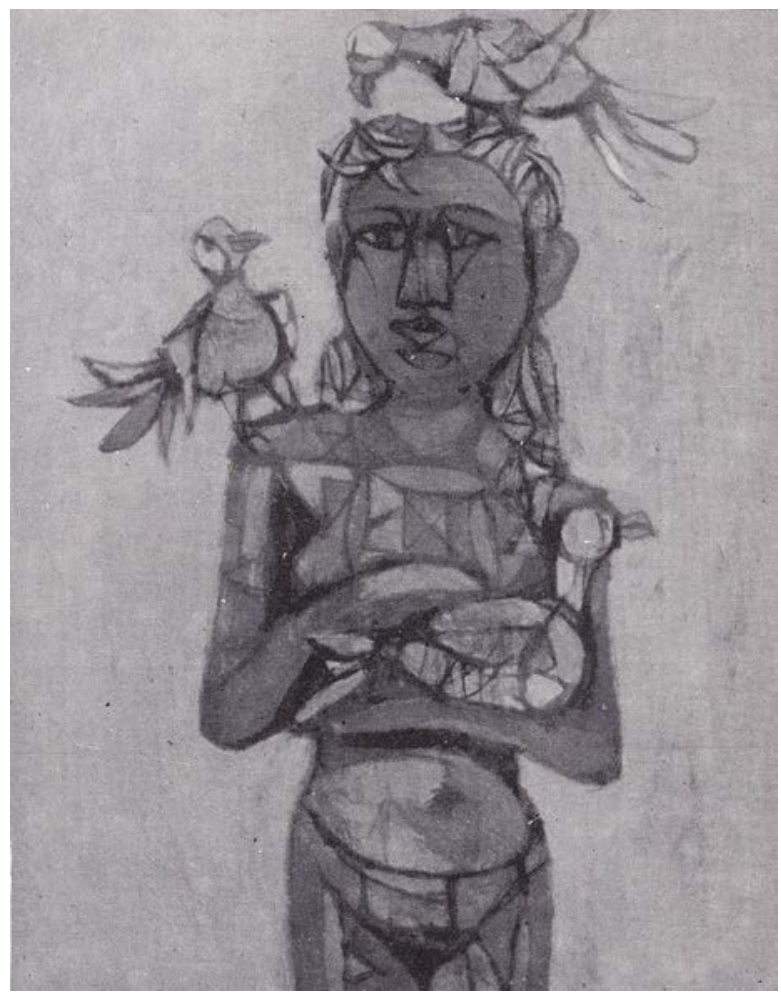

\section{Figure 1: Girl with pigeons, KG Subramanyan, 1959-1960}

Source: Geeta Kapur, KG Subramanyan (New Delhi: Lalit Kala Akademi, 1987), 27. ${ }^{11}$

They argued that Hindu iconography belonged to Indian visual culture generally and could be reinterpreted as any other piece of culture. In line with this, Subramanyan believed that all faiths and institutions should be subject to criticism as an essential part of culture. He viewed visual culture as an archive of images and ideas available to artists for citation. ${ }^{12}$ Figures 1 and 2 exemplify the way in which Subramanyan references two Hindu icons within identifiably modern painting styles.

10 ibid.

11 The images in this article are reproduced from Kapur's monograph on Subramanyan, in which the reproductions are black and white.

12 'Resisting Rigid Controls,' Art India, accessed 3 May 2013, <http://www.artindiamag.com/quarter03_07/ sandhya_bordewekar.html>. 
Subramanyan's oil painting Girl with pigeons (Figure 1) is a prime example of the assimilation of modernist and indigenous traditional elements. Painted between 1959 and 1960, the work displays the modernist simplification of forms and flattening of the image plane, its visual style appearing to draw from European modernist painters, particularly Henri Matisse. These modern elements are incorporated with elements of indigenous visual language. The painting cites the Hindu deity Rati, goddess of love, passion and sexual pleasure. While Subramanyan maintains distance from the religious potency of the icon, he simultaneously comments on and represents it. ${ }^{13}$ The painting imagines a modern iteration of Rati in the form of a young woman in the street. She is not dressed as a deity nor does she stand as one, however, the reference is made clear by the presence of the pigeons, the symbol of Rati. ${ }^{14}$ The purpose of Subramanyan's reference to the Hindu icon is twofold: firstly, it allows him to quickly communicate a representation of the girl as an object of sexual desire, drawing on the collective Indian understanding of its dominant Hindu culture; secondly and more importantly, Subramanyan is reclaiming Rati. He transplants the icon into a modern, secular context and, in doing so, reinvents both modern and indigenous tradition for a present purpose. Subramanyan saw his work as an interpenetration of religious content; an act which enlivened those icons rather than damaging them. ${ }^{15}$ Subramanyan shows that the elements of Indian indigenous tradition are in flux, their craft and language being reinvented rather than cast away.

The fluidity of tradition is highlighted in the modern period through the assimilation of modern, classical and popular visual cultures. This development was nowhere more apparent than in India, where many believed that the modernisation of indigenous traditional art was vital to its preservation. Tagore argued that Asia was defined by its tradition and should modernise 'on its own terms' ${ }^{16}$ As a universalist and a humanist, who saw himself as a custodian of world culture, Tagore had no qualms in combining modernist, popular, classical and indigenous traditions in the modern context. He declared that 'all traditional structures of art must have a sufficient degree of elasticity.' ${ }^{17}$ His artistic philosophy was outlined in the essay 'Art and Tradition' in which he urged Indian artists to deny their obligation to create anything that aligns with

13 Zitzewitz, 'Secular Icon', 16.

14 Nanditha Krishna, Sacred Animals of India (New Delhi: Penguin Books, 2010), 10, 11.

15 Zitzewitz, 'Secular Icon', 17, 22.

16 Alastair Bonnett, 'Occidentalism and Plural Modernities: How Fukuzawa and Tagore Invented the West', Environment and Planning D: Society and Space Vol. 23 (2005): 516

17 Ratan Parimoo, 'The Sources and the Development of Rabindranath's Paintings', in Rabindranath Tagore, edited by Ratan Parimoo (New Delhi: Lalit Kala Akademi, 1989), 31. 
the 'old world' idea of Indian art. ${ }^{18}$ Tagore's beliefs reflected those held by many Indian modernists: that the aim of modernism was not to suppress tradition, but to widen its bounds and create a single, global visual language. ${ }^{19}$

Profoundly influenced by Tagore's artistic practice, Subramanyan engaged with Tagore's eclecticism. ${ }^{20}$ Subramanyan believed multivalence to be endemic across Indian indigenous artistic tradition and a characteristic that was definitively Indian; ${ }^{21}$ he aimed for multivalence in his work to ensure that his meaning was left open to interpretation. Subramanyan's years at Visva-Bharati solidified for him the importance of drawing upon and reinventing tradition. Being welltravelled, well-read and having a good understanding of Indian as well as nonIndian cultures, Subramanyan was skilled at marrying the modernist, popular and classical traditions with the indigenous. ${ }^{22}$ His work illustrates how elements of modern and classical traditions can inform and reform an artist's practice.

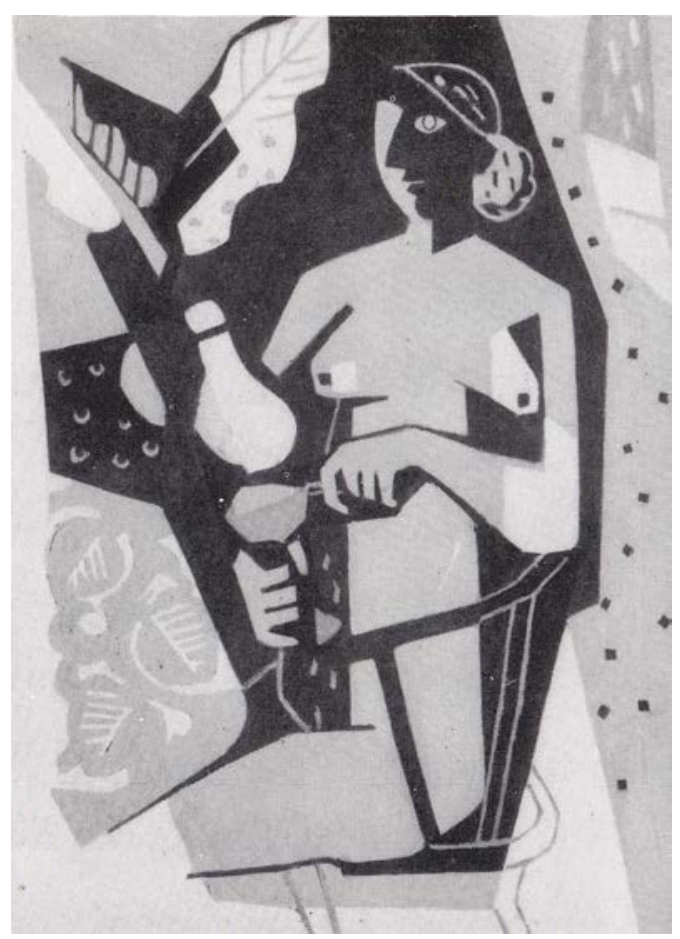

Figure 2: Woman with lamp 1, KG Subramanyan, 1951

Source: Kapur, Subramanyan, 24.

18 Rabindranath Tagore, 'Art and Tradition', in Rabindranath Tagore, 9.

19 JC Heesterman, 'India and the Inner Conflict of Tradition', Daedalus Vol. 102 No. 1 (1973): 111.

20 Margaret Richardson, 'Understanding the Importance of Eclecticism: KG Subramanyan and TwentiethCentury Indian Art', Southeast Review of Asian Studies Vol. 29 (2007): 245.

21 Zitzewitz, 'Secular Icon', 18.

22 Kapur, Subramanyan, 3. 
Woman with lamp 1 (Figure 2) is one of the many Western modernist experiments carried out by Subramanyan in the 1950s. ${ }^{23}$ The influence of European modernist artists is evident in the work, particularly Matisse and Pablo Picasso. The influence of Matisse is expressed in the painting's form and use of colour. Matisse's work strove for 'serenity' through simple contours and forms, and Subramanyan reflects this ideal in his use of solid blocks of flat colour, which dispense with volume and indicate form through line and shape instead. ${ }^{24}$ In Woman with lamp 1 colour blocks are stacked upon one another from light to dark to create the illusion of shadows and highlights. The simplification of form and flattening of the image plane is common to many early European modernist artworks and translates well into Subramanyan's art practice. References to Picasso can be seen in the multiple perspectives and dissection of the figure and her surroundings. ${ }^{25}$ In the image, a number of perspectives have been condensed into the image plane. The figure's face is represented in portrait, but the rounded form in the lower colour block implies a full-face view. The influences from European modernism on Subramanyan's work, and the ease with which these traditions are combined, can be seen as evidence of the fluidity of tradition. Subramanyan, in assimilating diverse traditions into his own practice, has reinvented modernism within a present, Indian context. In doing so he has strengthened and enlivened the Indian artistic tradition.

Industry (Figure 3) displays the integration of both classical and modern traditions. The subject matter is modern and placed in an Indian setting, but it is arranged in the style of a classical Greek or Roman fresco. The painting displays the characteristic compression of three-dimensional space that is typical of classical frescoes. The figures are stacked on top of one another to indicate depth and there is no visual perspective; the faces of each brick column are flattened, apparently perpendicular to the viewer's gaze. Many of Subramanyan's teachers at Visva-Bharati were interested in fresco painting and this is most likely the influence for the classical layout in this image. ${ }^{26}$ Modernist influences are also apparent in this painting, the theme of which is modernisation. These influences can be seen in Subramanyan's complex use of the gaze in this work. Initially the viewer's gaze is directed to a flattened perspective, which gives the impression of the image being viewed directly. More intriguing, however, is the use of the gaze amongst the figures, the majority of whom stand, absorbed in their task of observing the viewer. The figures are depicted with a wide, unsettling stare and an expressionless face. The diverse modern and classical elements in this painting have been smoothly translated into an Indian setting and Subramanyan has utilised the fluidity of tradition, reforming his artistic practice and reinventing these traditional elements for his present purposes.

23 Zitzewitz, 'Secular Icon', 20.

24 KG Subramanyan, The Living Tradition - Perspectives on Modern Indian Art (Calcutta: Seagull Books, 1987), 79 . 


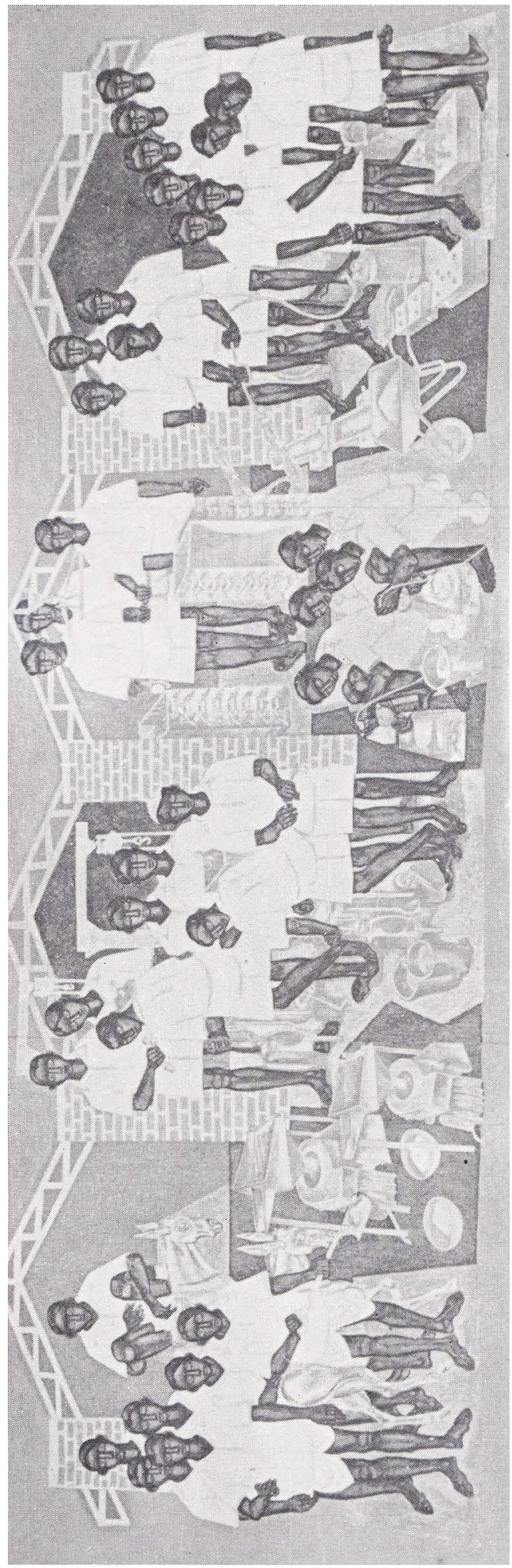

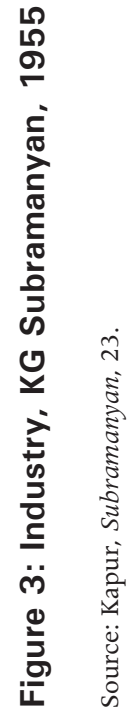


Tradition is a concept in constant contradiction. It is the basis on which a society and culture preserves its selfhood. Yet it must be constantly reinvented in order to be kept 'alive'. JC Heesterman describes this contradiction aptly, writing that tradition aspires to reach some fundamental and yet unreachable conclusion. ${ }^{27}$ It is this pursuit that keeps tradition in flux, yet firmly connected with the present. The conflict of tradition arises from a long-standing debate; does the reinvention of tradition preserve or undermine it? Tradition is often misunderstood as a cultural preserve. Nevertheless, while a society is concerned with maintaining its selfhood, it is also concerned with remaining a living, growing and evolving organism. Following this argument, elements of tradition that are not in present use are in decay. Tradition must be in continual use in order to be sustained.

Subramanyan's artistic and intellectual pursuits in the modern period have been concerned with the role of tradition in modern Indian culture. His experiments with interpenetration of Hindu iconography and the assimilation of popular, modern, classical and indigenous traditions have been vital to the revival of Indian visual culture. In continuing the work of Tagore and Bose, Subramanyan has enlivened Indian indigenous tradition and reinvented it for present purposes. His examination of tradition has influenced much of India's modern and contemporary art. As India undergoes rapid industrial modernisation, the question of whether culture ought to embrace modernism, or hold on to the past, inevitably arises. Traditions resisting change have either been reinvented and modernised without consent, or abandoned in favour of traditions that are applicable to an increasingly modern world. Modernism is not a suppression or supersession of tradition. Rather, it is a tradition by itself in a global context. The assimilation of modern and indigenous traditional elements allows tradition to fulfil its present purpose creating a global, modern visual culture. Tradition in modern India is alive, sustained by the work of artists such as Subramanyan. It is, if not by definition then by necessity, a fluid entity.

\section{Bibliography}

Art India, 'Resisting Rigid Controls', Accessed 3 May 2013, <http://www. artindiamag.com/quarter03_07/sandhya_bordewekar.html>.

Bonnett, Alastair, 'Occidentalism and Plural Modernities: How Fukuzawa and Tagore Invented the West', Environment and Planning D: Society and Space Vol. 23 (2005): 505-25.

27 Heesterman, 'India', 97-99. 
Heesterman, JC, 'India and the Inner Conflict of Tradition', Daedalus Vol. 102 No. 1 (1973): 97-113.

Kapur, Geeta, KG Subramanyan, New Delhi: Lalit Kala Akademi, 1987.

Khanna, Balraj \& Aziz Kurtha, Art of Modern India, London: Thames and Hudson, 1998.

Krishna, Nanditha, Sacred Animals of India, New Delhi: Penguin Books, 2010.

Kumar, R Siva, 'Modern Indian Art: A Brief Overview', Art Journal Vol. 58 No. 3 (1999): 14-21.

Parimoo, Ratan. 'The Sources and the Development of Rabindranath's Paintings', in Rabindranath Tagore, edited by Ratan Parimoo, New Delhi: Lalit Kala Akademi, 1989.

Richardson, Margaret, 'Understanding the Importance of Eclecticism: KG Subramanyan and Twentieth-Century Indian Art', Southeast Review of Asian Studies Vol. 29 (2007): 240-47.

Singh, Karan, 'A Fresh Perspective', Graphics Interface 2002: 17-24.

Subramanyan, KG, The Living Tradition - Perspectives on Modern Indian Art, Calcutta: Seagull Books, 1987.

Tagore, Rabindranath, 'Art and Tradition', in Rabindranath Tagore, edited by Ratan Parimoo, New Delhi: Lalit Kala Akademi, 1989.

Werness, Hope B, The Continuum Encyclopedia of Animal Symbolism in World Art, New York: Continuum, 2006.

Zitzewitz, Karin 'The Secular Icon', Visual Anthropology Review Vol. 24, No. 1 (2008): 12-28. 
This text taken from The ANU Undergraduate Research Journal Volume Five 2013, published 2014 by ANU Press, The Australian National University, Canberra, Australia. 